\title{
TEACHING LITERATURE THROUGH TRANSLATION - JOHN MILTON, DYLAN THOMAS AND T.S. ELIOT: PARALLELS WITH THE CORDOVAN SCHOOL OF MODERN POETRY
}

\author{
Juan de Dios Torralbo Caballero
}

University of Córdoba, Spain

E-mail: torralbocaballero@uco.es

\begin{abstract}
Literature is usually taught using primary sources written in the language of the literature being taught. This pedagogical proposal is based on translations of literature, advanced as a didactic element enhancing literature lessons. More specifically, this work focuses on English literature translated into Spanish and published in the Cordovan journal Cántico, in order to explore how the translations of international works can be valuable elements in the teaching of literature. To achieve these objectives some of the translations of the English works appearing in Cántico are studied: two fragments of John Milton, a poem by Dylan Thomas, and another poem by T.S. Eliot. The final conclusion drawn is that the interpretation of the original poems, their poets, and their context, as well as a presentation of the context in which these poems were translated, are pedagogical undertakings that enhance the teaching of foreign literature, and literature in general.
\end{abstract}

Key words: Literary Translation, Teaching Literature, Comparative Literature, Cántico

\section{INTRODUCTION}

This paper explores the relationship between language and literature; more specifically, between literature in translation, and the context surrounding the original works. The study of the interplay between literature and the society in which it is translated provides the scholar with important information. The inquiry presented here delves into the translations of foreign literature published in the Spanish literary review entitled Cántico (1947-1957).

The working hypothesis is that the election of the poets and poems to be translated helps us to better understand the literature of the target culture (in this case, Spain's) and its historical and literary circumstances. A study of the selection of the fragments translated, the topics they touch upon, their historical significance, and their relationship to the time of their publication, helps us to teach not just the source country's literature, but the target country's too, as the proper contextualisation of the literature in translation published in such a literary journal proves an expedient tool for the literature teaching and learning process.

At this time I am completing a research project that studies and analyses how translations were completed for the Cordovan journal (Torralbo 2018a). An illustration of what has already been carried out is the research on Eliot and Milosz; I had the opportunity, together 
with Professor Violeta Januleviciene (2018), to work on the two writers' presence in the journal. With all the previous research, it has been concluded that the translations in Cántico are texts that are very close to the content and distribution of the original poems, thereby offering the reader reliable recreations of the source texts. Therefore, in this paper I am not going to compare the original texts with their respective translations.

\section{THE JOURNAL CÁNTICO}

The literary journal Cántico took its name from the Cántico Espiritual by San Juan de la Cruz (1622) and Cántico by Jorge Guillén (1928). The literary journal was created by a group of young Cordovan poets in 1947: Ricardo Molina (1916-1968), Pablo García Baena (19232018) and Juan Bernier (1911-1989), together with Julio Aumente (1921-2006) and the painters Miguel del Moral (1917-1998) and Ginés Liébana (1921-). To better understand the journal, here I cite a description by the English Hispanist Charles David Ley, found in his doctoral thesis on said Spanish publication:

The periodical was primarily overseen by Ricardo Molina, and intended to showcase the existence of a Cordovan school of modern poetry -consisting mainly of the three editors. Some of the numbers were devoted to single poets, such as Molina himself, and Celaya. Local colour, of the typical Andalusian kind, which we find in Lorca and Alberti, is avoided by these introspective poets, who were concerned with religious problems, and frequently wrote in long free-verse lines. Molina, as Cántico's main editor, maintained extensive correspondence with other poets, both at home and abroad. Poets from all over Spain were published in Cántico. Space was given to translations of foreign poets; for instance, Dylan Thomas, after his death. Literary visitors to Cordoba were given a warm welcome by the Cántico group; Aleixandre, for instance, was there shortly after his health improved in 1949. (Ley, 1962: 241)

All the journals published, over the course of two periods (1947-1949 and 1954-1957) may be consulted in a painstakingly produced facsimile edition (AA.VV. 2007) published more than a decade ago, whose pages I follow for the references in this work, offering the quotes in a parenthetical way by means of the number of each page where the extracted texts are found. It is a lavish creation, produced even using the same type of paper as the original journal. The weight of the paper used in the recreation is the same as in the original publication, including the covers and back covers.

After the Spanish Civil War the literary scenario in the city of Córdoba was a logical reflection of a post-bellum situation. The Grupo Cántico (as these Spanish poets have been called) revitalized the city's poetry scene and served as a bridge to bring many foreign verses to Spain in the 40s and 50s. Pablo García Baena (2007) metaphorically alluded to Cordoba and "its indifferent marble", and to city that "was not exactly a city for poets". It was precisely because it overcame these adversities (not to mention that the journal was founded without notable external funding), García Baena acknowledged that the group would later be called the "Cordovan School".

The different issues of Cántico offer the reader a wide range of writers and international poems from various literatures: French, English, Italian, Portuguese, German and even Chinese, Hungarian and Russian. The English Literature appearing included works by Auden and Longfellow, two fragments from the $17^{\text {th }}$ century poet John Milton, as well as a series of early $20^{\text {th }}$ century poetry by the likes of T.S. Eliot, Dylan Thomas, Rathleen Lee, Lawrence Durrell and Nicholas Moore (Torralbo 2018b). 


\section{JOHN MILTON}

John Milton (1608-1674) is the author of the landmark work of poetry Paradise Lost. His impressive body of work includes a remarkable tragedy that the writer completed in 1671 . The fragments from the Puritan poet translated in the Cordovan literary review establish an interplay with the post-War context in which the country was immersed at that time. The journal contains, in particular, two fragments of the closet drama Samson Agonistes, one from the beginning of the work, and the other taken from the end. The tone infusing the English tragedy was one of pessimism and melancholy, revealing the republican, Puritanical author's dismay, as in 1660 the Commonwealth, which he supported, had come to an end, and Charles II installed on the throne in the era known as the Restoration. This first reflection allows me to conclude that the vein of the original text matches that of Spain's, in tune with the pessimism of post-War era in Spain. This is borne out by a careful reading of the poems and through a subsequent comparison of the societal frameworks in which both works were created.

The texts of John Milton are translated by the Hispanists Charles David Ley and José García Nieto, well-known writers in the literary circles of the time and who also collaborated on other creative works. The former was a language teacher in Madrid; the second the founder of another literary journal entitled Garcilaso.

The first excerpt appearing in Cántico is the Spanish version of the following twentyone verses that proceed - as has been stated - from the initial part of the English tragedy by John Milton:

O dark, dark, amid the blaze of noon,

Irrecoverably dark, total Eclipse

Without all hope of day!

$O$ first created Beam, and thou great Word,

Let there be light, and light was over all;

Why am I thus bereav'd thy prime decree?

The Sun to me is dark

And silent as the Moon,

When she deserts the night

$H i$ in her vacant interlunar cave.

Since light so necessary is to life,

And almost life itself, if it be true

That light is in the Soul,

She all in every part; why was the sight

To such a tender ball as th'eye confin'd?

So obvious and so easie to be quench't,

And not as feeling through all parts diffus'd,

That she might look at will through every pore?

Then I had not been this exil'd from light;

As in the land of darkness yet in light,

To live a life half dead, a living death,

And buried; [...] (Milton, 1980: 445)

The poem accords with the post-war Spanish milieu. For example, the third verse ("Without all hope of day!") is a faithful reflection of the relationship between translation and intrahistory, allowing for authorial hermeneutics of a very personal nature, as it contains an autobiographical allusion to Milton's blindness. It also lends itself to the examination of community and collective hermeneutics, as it alludes to the darkness that a war generates, and the desire for light and hope among the people of the country that endure the conflict. It also 
features strong religious symbolism, found in the references to the World (God) and the origin of creation appearing in the book of Genesis (which inspired Milton's Paradise Lost).

The second translated passage comes from the final part of the tragedy, and is a text that celebrates the victory of Samson through various images and a clearly hymn-like structure, in which prosody and parallel constructions (such as anaphora) play a preponderant role:

Semichor: But he thought blind of sight,

Despis'd and thought extinguish 't quite,

With inward eyes illuminated

His fierie vertue rouz'd

From under ashes into sudden flame,

And as an ev'ning Dragon came,

Assailant on the perched roosts,

And nests in order rang'd

Of tame villatic Fowl; but as an Eagle

His cloudless thunder bolted on this heads.

So virtue giv'n for lost,

Deprest, and overthrown, as seem'd,

Like that self-begott'n bird

In the Arabian woods embost,

That no second knows nor third,

And lay e're while a Holocaust,

From out her ashie womb now teem'd,

Revives, reflourishes, then vigorous most

When most unactive deem'd,

And though her body die, her fame survives,

A secular bird ages of lives. (Milton, 1980: 478)

It has already been mentioned that the references to blindness in John Milton's work reflect the author's own life, marked by this disability. This aspect of his biography is reflected more directly in his famous Sonnet XIX, which begins with the verse "When I consider how my light is spent." The said sonnet invites a reading based on the author's condition and, at the same time, a religious interpretation, as it reflects the devout faith of the Puritan writer (Torralbo, 2015), who patiently places his grief in the hands of God.

The reference to the revival of the character, like the phoenix, also alludes to an aspect of the life of the English writer, who, on occasion, lamented what he considered his creative sterility (an idea also found in the aforementioned sonnet). This sense of failure and the idea of renewal concurs with the Spanish context of the time, that of a country that was no longer at war, but was struggling with the reconciliation of its people, cultivating its future after a period of violent strife, and the polarization of two deeply antagonistic sides.

It can be seen, then, how the literature translated reflects and points to history and intrahistory, as evidenced by the examples of light, the lack of vision, and the figure of Samson, along with a notable set of obvious social, historical and personal connotations.

This political bifurcation allows the teacher to trace two groups of poets, for pedagogical purposes, in the interest of effective learning - even though each writer, as is only natural, displayed, in turn, a series of associated nuances that do not allow us to pigeonhole them in one faction or another in a categorical or definitive way. An example, within English literature, is the teaching of John Milton, as opposed to the Cavalier, or monarchical poets, such as John Wilmot (Earl of Rochester), Aphra Behn, and John Dryden in his second ideological stage. 


\section{DYLAN THOMAS}

Dylan Thomas (1914-1953) is a $20^{\text {th }}$ century English poet born in Wales (Swansie), whose legacy was marked by his perspectives on war. In fact, the translated poems of Dylan Thomas infuse the Cordovan magazine with martial themes, highlighting the desolation wrought by warfare.

Another poem is "Among those Killed in the Dawn Raid was a Man Aged a Hundred", whose subject, a massacre in the midst of war, revolves around an old man and his surroundings. The realism of the poem is starkly eloquent:

When the morning was waking over the war

I put on his clothes and stepped out and he died,

The locks yawned loose and a blast blew them wide,

He dropped where he loved on the burst pavement stone

And the funeral grains of the slaughtered floor.

Tell his street on its back he stopped a sun

And the craters of his eyes grew springshoots and fire

When all the keys shot from the locks, and rang.

Dig no more for the chains of his grey-haired heart.

The heavenly ambulance drawn by a wound

Assembling waits for the spade's ring on the cage.

Or keep his bones away from that common cart,

The morning is flying on the wings of his age

And a hundred storks perch on the sun's right hand. (147)

The poem draws its title from a story in a newspaper of the time (Goodby, 2013), depicting the harsh reality of a bombing in Hull and its dire consequences. This realism is what the Cordovan magazine injects into its pages through this poem, faithfully captured by the well-known Spanish translator Marià Manent. To better understand this type of writing and the originality and peculiarity of the title, it is worth noting that Dylan Thomas also worked as a journalist.

There is another poem by the Welsh writer entitled "The Hand ...", which touches on the serious consequences of the deadly decisions of those in power. The poem, through the synecdoche of a hand that signs a document, condemns the taking of a decision to go to war, and the blood that it will spill. The poem is composed of four similar stanzas, each of four verses. It begins:

The hand that signed a paper felled a city;

Five sovereign fingers taxed the breath,

Doubled the globe of dead and halved a country;

These five kings did a kind to death. (301)

The translator was the philologist Charles David Ley, a writer who merits study himself, and has not been researched thus far. (Ley was born in London, but lived for a long period in Spain, where he worked as a teacher and moved in circles of poets. Ley even published poems of his own, translated Spanish literature into Portuguese, and also translated Spanish literature into English).

Returning to the pedagogy of literature, it should be noted that Thomas and his legacy, specifically his writing about war, allow the teacher to connect his teaching to the Spanish revolutionary poetry of the 50s, as in the case of José Hierro (1951: 116) who wrote that "If 
any poem of mine is perhaps read in a hundred years' time, it will be not for its poetical but its documentary value" (Ley, 1962), or Gabriel Celaya (1951) : 11) who wrote the following postulate: "Poetry is not an end in itself. Poetry is an instrument, with us, for changing the world”, which I also include, using the translation by Charles David Ley (1962: 111).

\section{T.S. ELIOT}

Thomas Stearns Eliot (1988-1965) is another twentieth-century poet who was born St Louis (USA) and became a British citizen. His merit and poetic quality are certified, inter alia, by the Nobel Prize for Literature he was awarded in 1948.

The Cordovan journal published a Spanish translation of his poem "The Hollow Men" (124-125), produced by Antonio Muñoz Rojas, a poet hailing from Antequera (Malaga) and belonging to Spain's Generation of '36. The text is related to the themes of Eliot's best-known poem, The Waste Land: fragmentation and devastation. It begins like this:

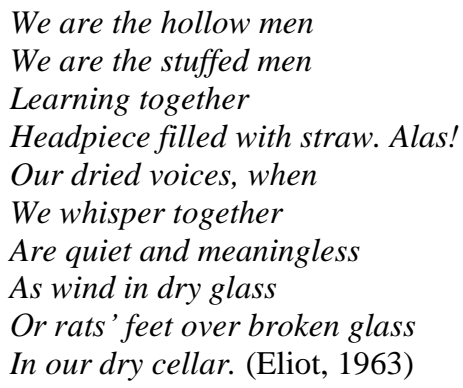

The nihilism that T.S. Eliot's poems convey reflects the writer's background and, at the same time, his emotional intensity. These thematic and rhetorical elements mirror (in the literary document of the translators) the historical context of Spain at the time, characterised by a similar weariness and existential ennui.

In fact, this translation provides the pedagogue with an opportunity to explain the context of Modernist poetry, the hallmarks of Modernism (for example, fragmentation, innovation, freedom of technique, intertextuality, etc.) and to delve into coverage of T.S. Eliot, as an individual, along with other poets of the era, like Ezra Pound.

Another didactic angle that may be taken involves the literary influences that the poet evidences; for example, T.S. Eliot's work contains elements indicating the influence of Elizabethan and Jacobean theatre, metaphysical poetry (John Donne), the Spanish mystical literature of San Juan de la Cruz, Victorian poetry (Browning and Tennyson), French symbolism, as well as Dante. In this regard, it should be noted that Eliot masterfully wrote about literary influences in his essay "Tradition and the Individual Talent" (Eliot, 1997).

In short, translators function as cultural mediators who transmit content (stylistic, thematic, ideological) from the source culture to the target one. Germane here is the description of Susan Bassnett (2011) of translators as "cross-cultural mediators" who facilitate "communication, understanding an action between persons or groups who differ with respect to language and culture". 


\section{COMPLEMENTARY EXAMPLES AND OTHER IMPLICATIONS FOR TEACHING}

Before concluding I wish to note that the journal contained a whole plethora of notable foreign poets, many more than I have included in this work, limited to a few examples of English poetry included, in Spanish, in the Cordovan publication.

A good example is the presence of Italian literature, translated by Ricardo Molina. In this case, the Spanish poet first translated a fragment of "La morte meditate" by Giuseppe Ungaretti, together with "Tutto ho perduto" (205-216). Second, Ricardo Molina presented his translation of the poem "L'Anguilla" (232) by Eugenio Montale. Ricardo Molina translated "Casi un Madrigal", forming part of the legacy of Salvatore Quasimodo. Finally, Molina added his translation of "L'Italia" by Pier Paolo Pasolini (234-236). These examples illustrate the international orientation of the Spanish journal serving as the basis and focus of this work. The inclusion of these poems denotes the innovative nature of the Cordovan poets, as well as the journal's clearly international aspirations.

The study of these translations can complement instruction examining the renewal of verse that took place during the first half of the $20^{\text {th }}$ century. These examples are from Italian poetry, but the teacher can apply this class scheme to other countries, or even relate Italian poetry to English or Spanish, emphasise their similarities and differences, offering the student a more holistic and universal perspective. Such an approach is of great utility and relevance to a Comparative Literature lesson.

Another range of foreign works included French poetry, which figured prominently in the Cordovan poets' journal. Lubics Milosz has been cited; it must be clarified that Milosz lived in France and wrote in French. Along with Milosz, of note were Paul Claudel, Péguy, Francis Jammes, André Gide, Pierre Enmanuel, Louis Aragon, Francis Ponge, Jacques Prevert, Eugène Guillevic, René Guy Cadou and René Char, among others. This broad range of French literature also demonstrates Cántico's openness and international nature.

Another implication of the texts, in both their original and translated versions, is worthy of mention in this work. I believe that the study of texts (source and target) serves as a didactic device not only for literature and culture per se, but also for language. Based on this premise, I contend that poems written in English constitute a valuable tool for the learning of specific lexical terms and understanding their meaning.

In many foreign language classes works of literature are used as complementary reading, for pedagogical support, sometimes of graduated difficulty, adapted to the level of the students. In fact, we have a book that teaches English through a set of literary texts, published in Spain, constituting a practical application of the above (Hidalgo \& Alcaraz, 1988). One example of this is the section on the Romantic poet Samuel Taylor Coleridge's "Kubla Khan", divided into a clear introduction to the author; the poem itself, with many words explained in the margin with concise definitions; a brief literary textual analysis and, finally, two concrete activities to enhance one's learning and the acquisition of vocabulary.

\section{RESULTS}

The themes of the translated poems fit right in with the post-War landscape that the Spanish writers of the time inhabited. These translations serve as a kind of bridge and cultural mediator, transcending the literary importation itself.

Translators are also cultural ambassadors of a source culture towards a target culture, in this way bringing a foreign literature closer to a new set of readers, both real and potential. 
The content of the poems is integrated into the target literature, from this moment forward generating a series of new semantic impacts that even influenced other poets (a clear example of this is the influence of Paul Claudel on Ricardo Molina).

The cases analysed allow us to appreciate the translation of poetry as an activity having the potential to establish a dialogue with intrahistory. In this way we see how these translations echoed the hardships of Spain at the time they were written and published.

Another question that arises is how the directors of the publication and the translators came into contact; that is the relationships between the Cordovan poets of the Grupo Cántico who ran the review and the translators published in the journal's pages, because translations generate human relationships between poets, and socialization networks. In the examples analysed here, it is glaring and noticeable the Grupo Cántico's apparent relationships with a set of well-known Hispanists, including Charles David Ley and José Luis Cano, among other leading literary and cultural figures.

\section{CONCLUSION}

The translations of English poetry contained in the review Cántico spur us to reflect on the situation in Spain in the 1940s and 1950s. These translations constituted vital international literary bridges with the country, and allow us to study the translators themselves, and better understand the context in which their translations were produced.

Translators thus serve as cultural mediators who planted fertile seeds of foreign literature on Spanish soil, which flourished precisely due to the historical context of the era in Spain, and that would germinate in the future, either in the hands of readers, or in other literary works reflecting that literature's influence.

I infer that the poems translated in this work, with their respective contexts, complement and facilitate the teaching of Spanish Literature (and also English) because they reflect the context shaping Spanish literature after 1939. This conclusion should be of great interest to students of Spanish Literature who have a background in English Literature.

\section{REFERENCES}

AA.VV. (1952). Antología consultada de la joven poesía española. Santander: Hermanos Bedia.

AA. VV. (2007). Cántico. Hojas de poesía, 1947-1957. Córdoba: Diputación Provincial de Córdoba, Consejería de Cultura de la Junta de Andalucía y Fundación Cajasur.

Bassnett, S. (2011). "The Translator as Cross-Cultural Mediator". In: K. Malmkjar \& K. Windle, eds. The Oxford Handbook of Translation Studies. Oxford: Oxford University Press, 1-9.

García Baena, P. (2007). "Nacimiento de Cántico". In: AA. VV. Cántico. Hojas de poesía, 1947-1957. Córdoba: Diputación Provincial de Córdoba, Consejería de Cultura de la Junta de Andalucía y Fundación Cajasur, XVII-XVIII.

Eliot. T.S. (1969). The Collected Poems 1909-1962. London: Faber and Faber.

Eliot. T.S. (1997). "Tradition and the Individual Talent". In: The Sacred Wood. Essays on Poetry and Criticism, 39-49.

Goodby, John (2013). The Poetry of Dylan Thomas: Under the Spelling Wall. Liverpool: Liverpool University Press.

Hidalgo, P. \& E. Alcaraz (1992). La literatura inglesa en los textos. Alcoy: Editorial Marfil. 
Ley C.D. (1962). Spanish Poetry Since 1939. Washington: The Catholic University of America Press.

Milton, J. (1980). The Complete Poems. G. Campbell, ed. London: J.M Dent \& Sons Ltd. Torralbo Caballero, J.D. (2015). "Both of them I serve, and of their train am I': Milton, the enraptured poet-prophet in his sonnets". Rozprawy Humanistczne, 16, 7.15.

Torralbo Caballero, J.D. \& V. Januleviciene (2018). "The Scope of Poetic Discourse in Cántico: The case of T.S. Eliot and O. V. de L. Milosz Translations". In: A. Giedre Raisiene \& Y. Bilan, eds. The $5^{\text {th }}$ European Interdisciplinary Forum 2017. Drivers for Progress in the Global Society, Bologna: Editografica, 207-214.

Torralbo Caballero, J.D. (2018a). "La 'afín universalidad' de la revista Cántico: presentación y estudio de los transvases internacionales". Impossibilia, 16, 136-174.

Torralbo Caballero, J.D. (2018b). "Literatura inglesa en las hojas de Cántico". Monteagudo, $23,169-186$. 